\title{
Dimensional Stability, Color Change, and Durability of Boron-MMA Treated Red Jabon (Antochephalus macrophyllus) Wood $^{1}$
}

\author{
Trisna PRIADI ${ }^{2} \cdot$ Gema ORFIAN $^{2}$ • \\ Tekat Dwi CAHYONO ${ }^{3, \dagger} \cdot$ Apri Heri ISWANTO ${ }^{4}$
}

\begin{abstract}
Boron compound had many advantages as wood preservative, but it was prone to leaching. Improving boron preservation was required to extend the service life of fast growing and low durability red jabon (Antochephalus macrophyllus) hardwood. This study aimed to evaluate the dimensional stability, color change and durability of modified red jabon wood by double impregnation with boron and methyl methacrylate (MMA) and heat treatment. Impregnation I used boric acid or borax, and impregnation II used MMA, while heat treatment used temperatures of $90{ }^{\circ} \mathrm{C}$ or $180{ }^{\circ} \mathrm{C}$ for 4 hours. The dimensional stability, leachability, water absorption, color change and decay resistance of modified red jabon wood were tested. The results showed that MMA impregnation increased the dimensional stability of red jabon wood, while the leaching and water absorption in the wood significantly reduced. Heating at $180{ }^{\circ} \mathrm{C}$ caused less water absorption and higher dimensional stability of the wood than that of heating at $90{ }^{\circ} \mathrm{C}$. Impregnation with boric acid and MMA followed by heating at $90{ }^{\circ} \mathrm{C}$ resulted in the highest wood $A S E, 89.9 \%$. The color change $\left(\Delta E^{*}\right)$ of wood increased significantly after MMA impregnation and heating at $180{ }^{\circ} \mathrm{C}$. Boric acid impregnation caused more resistant wood than borax impregnation against decay fungi and termites. Impregnation with boric acid and MMA followed with heating at $180{ }^{\circ} \mathrm{C}$ increased significantly the wood resistance against decay fungi and termites.
\end{abstract}

Keywords: decay fungi, fast growing wood, heat treatment, impregnation, leaching, dimensional stability, wood color

\section{INTRODUCTION}

Red jabon (Anthocephalus macrophyllus) was a fast-growing hardwood with specific gravity and density of 0.48 and $0.45 \mathrm{~g} / \mathrm{cm}^{3}$ respectively (Lempang, 2014; Cahyono et al., 2015). This wood had a cylindrical trunk, high branch-free area, and good veneer quality (Cahyono et al., 2016). Red jabon wood according to Indonesian National Standard (known as Standar Nasional Indonesia/SNI) had strength class III (Cahyono et al., 2012) and durability class IV (Halawane, 2015). Therefore, quality improvement of red jabon wood was

\footnotetext{
${ }^{1}$ Date Received December 17, 2019, Date Accepted April 23, 2020

2 Department of Forest Products, Faculty of Forestry, IPB University. Bogor 16680, Indonesia

${ }^{3}$ Faculty of Agriculture, University of Darussalam Ambon, Batu Merah, Ambon 97128, Indonesia

${ }^{4}$ Department of Forest Product, Faculty of Forestry, Universitas Sumatera Utara, Padang Bulan, Medan 20155, Indonesia

$\dagger$ Corresponding author: Tekat Dwi CAHYONO (e-mail: tekatdwicahyono@gmail.com, ORCID: 0000-0002-3010-7656)
} 
needed especially in the resistance to wood destroying organisms. The quality of wood could be improved with wood modification, such as chemical impregnation and heat treatment.

Impregnation of wood preservative in a pressure tank had been a commercial method in producing durable wood (Hadi et al., 2018). Boric acid and borax were boron preservatives commonly used in wood preservation (Salman et al., 2014; Jebrane and Heinmaa, 2016). Boron compounds were good efficacy-preservative for protecting wood from fungi and insects (Kartal et al., 2019). However, the main problem of boron preservative was prone to leaching in a wet environment (Lesar et al., 2009). Various manipulations had been made to reduce this weaknesses, one of them was by adding the bulking agent. Methyl methacrylate (MMA) was bulking agent material and might be used to improve wood properties (Yalinkilic et al., 1998; Ding et al., 2011). MMA was a colorless and volatile liquid (Dormer et al., 1998) that could improve the physical and mechanical properties of wood (Hadi et al., 2013; Cahyono et al., 2020).

Heat treatment was an environmentally friendly technique for wood quality improvement (Aydemir et al., 2011; Sandberg et al., 2017; Priadi et al., 2019). The temperature of wood heat treatment was generally above $100{ }^{\circ} \mathrm{C}$, or between $150-230{ }^{\circ} \mathrm{C}$ (Coto et al., 2015; Romagnoli et al., 2015). Heat treatment could improve the dimensional stability of wood (Lee and Lee, 2018; Priadi et al., 2019), its resistance to decay fungi (Kim et al., 2018; Park et al., 2018) and reduce wood hygroscopicity (Tomak et al., 2011; Chang et al., 2019).

The objective of this research was to evaluate the dimensional stability, color chage and durability of modified red jabon wood by double impregnation with boron and methyl methacrylate (MMA) and heat treatment.

\section{MATERIALS and METHODS}

\subsection{Materials preparation}

Red jabon (Anthocephalus macrophyllus Roxb. Havil) boards were cut from a 9-year-old tree, 3 trunks that had an average diameter at breast height of 40 $\mathrm{cm}$. The woods were taken from the community forest in Bogor, Indonesia and highly selected to obtain the flawless trunks. The test sample was a board taken from a wood part with the distance of $50 \mathrm{~cm}$ above the ground and $8 \mathrm{~cm}$ from the wood pith. The boards were dried in an experimental drying kiln at $40{ }^{\circ} \mathrm{C}$ to gain moisture content of $10 \%$. Then the boards were turned into different test samples. The sample size for dimensional stability, color, leaching, laboratory and field decay tests were $2.5 \times 2.5 \times 10 \mathrm{~cm}^{3}, 2.5 \times 2.5 \times 5 \mathrm{~cm}^{3}, 2$ $\times 2 \times 1 \mathrm{~cm}^{3}, 2.5 \times 2.5 \times 5 \mathrm{~cm}^{3}$ and $2 \times 2 \times 37 \mathrm{~cm}^{3}$ respectively. Each test used five replication of samples.

Boric acid, borax and methyl methacrylate (MMA) were used as impregnants. Boric acid and borax solutions were made at 5\% concentration each for impregnation I. MEPOXE M (Methyl Ethyl Ketone Peroxide) was used as the catalyst for curing MMA, which was mixed at ratio 1:10 before impregnation II.

\subsection{Impregnation and heat treatment}

The impregnation treatment were in two stages then followed by heat treatments at temperatures of $90{ }^{\circ} \mathrm{C}$ or $180{ }^{\circ} \mathrm{C}$ for 4 hours, as described in Table 1 . The impregnation was conducted in pressure wood treatment equipment at 5 atmospheric pressure for 4 hours. Before the impregnation II, the samples were oven-dried at $103 \pm 2{ }^{\circ} \mathrm{C}$. Heat treatments were conducted after impregnation II at temperatures of $90{ }^{\circ} \mathrm{C}$ or $180{ }^{\circ} \mathrm{C}$ for 4 hours in an electrical heating oven. The total amount of time required for the process of impregnation I, II and heat treatment was three days. 
Dimensional Stability, Color Change, and Durability of Boron-MMA

Treated Red Jabon (Antochephalus macrophyllus) Wood

Table 1 Combination of double impregnation and heat treatments

\begin{tabular}{lccc}
\hline Impregnant I & Concentration (\%) & Impregnant II & Heating \\
\hline \hline No Preservative & - & No MMA & $90{ }^{\circ} \mathrm{C}, 4 \mathrm{hrs}$ \\
Boric acid & 5 & No MMA & $90{ }^{\circ} \mathrm{C}, 4 \mathrm{hrs}$ \\
Borax & 5 & No MMA & $90{ }^{\circ} \mathrm{C}, 4 \mathrm{hrs}$ \\
No Preservative & - & MMA & $90{ }^{\circ} \mathrm{C}, 4 \mathrm{hrs}$ \\
Boric acid & 5 & MMA & $90{ }^{\circ} \mathrm{C}, 4 \mathrm{hrs}$ \\
Borax & 5 & MMA & $90{ }^{\circ} \mathrm{C}, 4 \mathrm{hrs}$ \\
No Preservative & - & No MMA & $180{ }^{\circ} \mathrm{C}, 4 \mathrm{hrs}$ \\
Boric acid & 5 & No MMA & $180{ }^{\circ} \mathrm{C}, 4 \mathrm{hrs}$ \\
Borax & 5 & No MMA & $180{ }^{\circ} \mathrm{C}, 4 \mathrm{hrs}$ \\
No Preservative & - & $180{ }^{\circ} \mathrm{C}, 4 \mathrm{hrs}$ \\
Boric acid & 5 & MMA & $180{ }^{\circ} \mathrm{C}, 4 \mathrm{hrs}$ \\
Borax & 5 & MMA & $180{ }^{\circ} \mathrm{C}, 4 \mathrm{hrs}$ \\
\hline
\end{tabular}

\subsection{Dimensional stability and wood color}

Dimensional stability, water absorption and leaching tests were done by soaking wood samples in water for 2, 24 and 48 hours. Each soaking was followed by oven drying at $103 \pm 2{ }^{\circ} \mathrm{C}$ to a constant weight. Dimensional measurements were made before and after soaking using digital caliper. Weighing the samples were carried out before and after water soaking in both wet and dry conditions. Then the volumetric swelling from air dry to wet conditions were determined using Equation 1. The anti-swelling efficiency $(A S E)$ was calculated with Equation 2. Dimensional shrinkage of wood in both tangential and radial directions were determined from wet to dry condition using Equation 3. The tangential-radial shrinkage ratio was calculated using Equation 4, while water absorption and leachant were calculated using Equations 5 and 6 respectively.

$$
\begin{aligned}
& S=\frac{V_{w}-V_{i}}{V_{i}} \times 100 \\
& A S E=\frac{S_{c}-S_{t}}{S_{c}} \times 100 \\
& S H=\frac{D_{w}-D_{o}}{D_{w}} \times 100 \\
& T / R=\frac{S H_{t}}{S H_{r}}
\end{aligned}
$$

$$
\begin{aligned}
& W A=\frac{W_{w f}-W_{o i}}{W_{o i}} \times 100 \\
& L=\frac{W_{o i}-W_{o f}}{W_{o i}} \times 100
\end{aligned}
$$

Where:

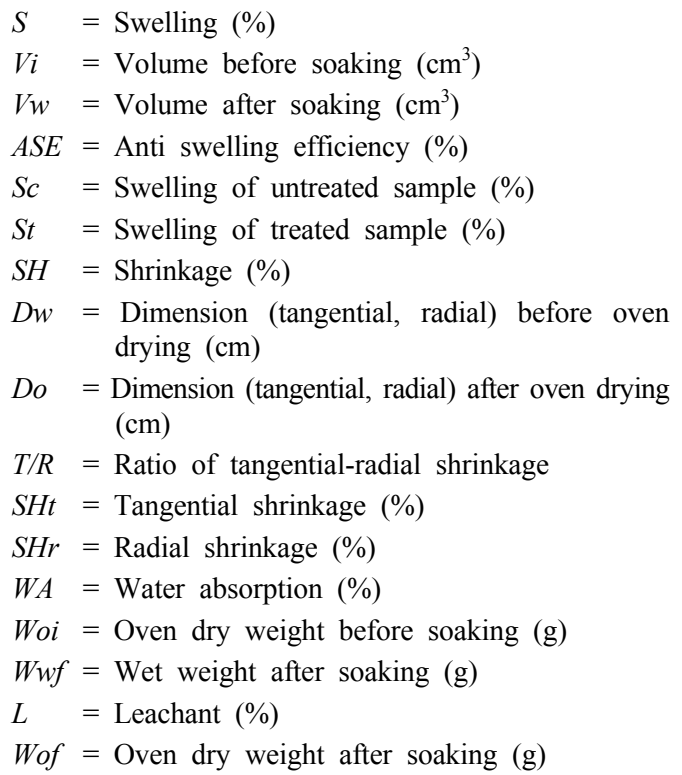

Wood color evaluation began with scanning of a wood surface with CanoScan 4400F scanner (color dpi resolution of $4800 \times 9600)$. Then ImageJ program was used to determine $L^{*} a^{*} b^{*}$ values before and after 
treatments at the same three positions on the wood surface image. In the CIELab system, the value $L^{*}$ was a lightness parameter with values 0 (black) to 100 (white). The $a^{*}$ chromatic value represents red (+) to green (-), while $b^{*}$ chromatic value represents yellow $(+)$ to blue (-) (Christie, 2014). The color change $\left(\Delta E^{*}\right)$ of wood was calculated based on Equation 7 and classified as negligible (0-0.5), slightly perceivable (0.5-1.5), noticeable (1.5-3.0), appreciable (3.0-6.0), very appreciable (6.0-12.0), and totally changed (more than 12.0) (Cui et al., 2007, Hidayat et al., 2017).

$$
\Delta E^{*}=\left[\left(\Delta L^{*}\right)^{2}+\left(\Delta a^{*}\right)^{2}+\left(\Delta b^{*}\right)^{2}\right]^{1 / 2}
$$

Where:

$$
\begin{aligned}
\Delta \mathrm{E}^{*} & =\text { Color change } \\
\Delta L^{*} & =L^{*} \text { after }-L^{*} \text { before treatment } \\
\Delta a^{*} & =a^{*} \text { after }-a^{*} \text { before treatment } \\
\Delta b^{*} & =b^{*} \text { after }-b^{*} \text { before treatment }
\end{aligned}
$$

\subsection{Decay test}

The resistance of wood to decay fungi was tested based on SNI 7207: 2014 standard (BSN, 2014) with a slight modification, after determining oven dry weight, the samples were wetted to facilitate fungal growth by dipping shortly in sterile water. The wood samples were oven dried at $103 \pm 2{ }^{\circ} \mathrm{C}$ until a constant weight. Furthermore in a laminar air flow, wood sample was put into a petri dish where decay fungi, Schizophyllum commune has been grown and covered potato dextrose agar (PDA) medium. After 12 weeks incubation at room temperature, the wood sample was cleaned and oven dried at $103 \pm 2{ }^{\circ} \mathrm{C}$ until a constant weight to determine weight loss due to fungal attack using Equation 8.

The field test of wood resistance to termite was conducted at the Arboretum of Faculty of Forestry, IPB University. Test samples were oven dried at $103 \pm 2{ }^{\circ} \mathrm{C}$ to a constant weight. According to ASTM D 1758-06 standard (ASTM, 2006), the sample was exposed in ground contact and buried up to $2 / 3$ of its length. The row and lane spacing between samples were $30 \mathrm{~cm}$ and $60 \mathrm{~cm}$ respectively. The sample placement points in the field were marked and then the samples were placed randomly on those marked points. After three months exposure, the samples were cleaned and oven dried at $103 \pm 2{ }^{\circ} \mathrm{C}$ to a constant weight. The weight loss of wood sample was determined by Equation 8 .

$$
W L=\frac{W_{i-} W_{t}}{W_{i}} \times 100
$$

Where:

$$
\begin{aligned}
& W L=\text { Weight loss }(\%) \\
& W i=\text { Dry weight of sample before test }(\mathrm{g}) \\
& W t=\text { Dry weight of sample after test }(\mathrm{g})
\end{aligned}
$$

\subsection{Data analysis}

The effects of impregnation and heating on the dimensional stablity, color change and durability of red jabon wood were analyzed statistically using a completely randomized factorial design. The experiment design included three variable factors of treatment with five replications. The factors were preservative (no preservative, boric acid and borax), monomer (no MMA and MMA), and heating temperature $\left(90^{\circ} \mathrm{C}\right.$ and 180 ${ }^{\circ} \mathrm{C}$ ). Analysis of variance was followed by Duncan test when there was a significant effect at the $95 \%$ confidence level. The data were processed using Microsoft Excel 2013 and IBM SPSS Statistic 22.0.

\section{RESULTS and DISCUSSION}

\subsection{Leachability}

According to Williams and Amburgey (1987), wood preservation with boron cannot be used in ground contact due to boron susceptible to leaching. Therefore, the use of boron preservative requires a leaching test to assess the stability of boron in wood. This research revealed that leachant in impregnated red jabon wood with borax was significantly higher than that of 
Dimensional Stability, Color Change, and Durability of Boron-MMA

Treated Red Jabon (Antochephalus macrophyllus) Wood

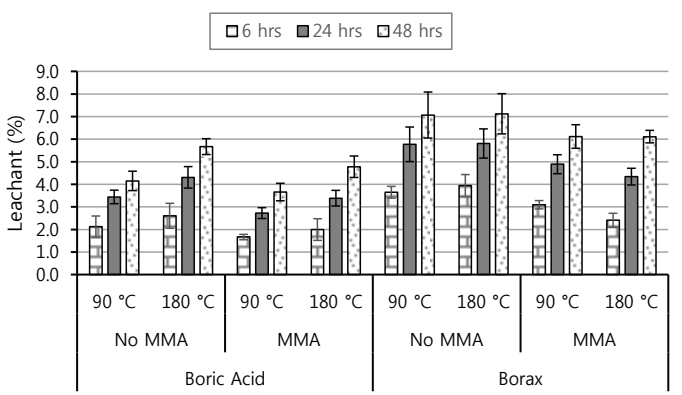

Fig. 1. Leachant of modified red jabon wood with impregnation and heating.

impregnated red jabon wood with boric acid, which means that borax preservative was more prone to leaching than boric acid. However, the use of MMA significantly reduced leaching of boron preservatives (borax and boric acid) in red jabon wood (Fig. 1). This could be caused by bulking agent effect of MMA in wood that inhibited the movement of boron compounds that had been previously impregnated into the wood. As the report of Hadi et al. (2013) that MMA entered cavities in wood experiences polymerization after heating and made wood denser. In addition according to Muberra

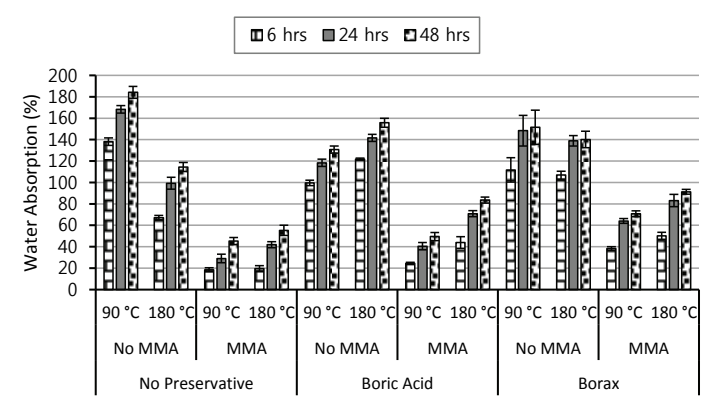

Fig. 2. Water absorption of modified red jabon wood with impregnation and heating.

(2016), a trans-esterification reaction could occur between polymethyl methacrylate to an aromatic boron compound.

\subsection{Water absorption}

Impregnation and heat treatment changed the water absorption of red jabon wood (Fig. 2). Analysis of variance and Duncan test revealed that water absorption of red jabon wood reduced significantly by boron (borax and boric acid) preservation and MMA impregnation (Table 2). The water absorption was also reduced by

Table 2. The Analysis of variance resume of the leachant $(L)$, water absorption (WA), anti-swelling efficiency $(A S E)$, tangential-radial shrinkage ratio $(T / R)$, color change $\left(\mathrm{D} E^{*}\right)$, weight loss of decay test in laboratory $(W L L)$ and field $(W L F)$ scales.

\begin{tabular}{|c|c|c|c|c|c|c|c|}
\hline & $\begin{array}{c}\text { Statistical } \\
\text { Values }\end{array}$ & $L$ & $W A$ & $T / R$ & $\Delta E^{*}$ & $W L L$ & $W L F$ \\
\hline $\mathrm{B}$ & $\begin{array}{c}\mathrm{F} \\
\text { (P-value) }\end{array}$ & $\begin{array}{r}152.76 \\
(0)^{* *}\end{array}$ & $\begin{array}{c}73.47 \\
(0)^{* *}\end{array}$ & $\begin{array}{c}4.144 \\
(0,022)^{*}\end{array}$ & $\begin{array}{c}2.591 \\
(0,085) \mathrm{ns}\end{array}$ & $\begin{array}{r}5.17 \\
(0,009)^{* *}\end{array}$ & $\begin{array}{r}38.849 \\
(0)^{* *}\end{array}$ \\
\hline MMA & $\begin{array}{c}\mathrm{F} \\
\text { (P-value) }\end{array}$ & $\begin{array}{r}59.935 \\
(0)^{* *}\end{array}$ & $\begin{array}{r}4562.387 \\
(0)^{* *}\end{array}$ & $\begin{array}{c}0.063 \\
(0.802) \mathrm{ns}\end{array}$ & $\begin{array}{r}487.252 \\
(0)^{* *}\end{array}$ & $\begin{array}{c}0.001 \\
(0.977) \mathrm{ns}\end{array}$ & $\begin{array}{r}467.826 \\
(0)^{* *}\end{array}$ \\
\hline $\mathrm{H}$ & $\begin{array}{c}\mathrm{F} \\
\text { (P-value) }\end{array}$ & $\begin{array}{c}0.358 \\
(0.552) \mathrm{ns}\end{array}$ & $\begin{array}{r}321.505 \\
(0)^{* *}\end{array}$ & $\begin{array}{c}0.779 \\
(0.382) \mathrm{ns}\end{array}$ & $\begin{array}{r}280.316 \\
(0)^{* *}\end{array}$ & $\begin{array}{r}94.412 \\
(0)^{* *}\end{array}$ & $\begin{array}{c}6.85 \\
(0.012)^{*}\end{array}$ \\
\hline $\mathrm{B} \times \mathrm{MMA}$ & $\begin{array}{c}\mathrm{F} \\
\text { (P-value) }\end{array}$ & $\begin{array}{c}4.588 \\
(0.015)^{*}\end{array}$ & $\begin{array}{r}23.755 \\
(0)^{* *}\end{array}$ & $\begin{array}{c}1.395 \\
(0.258) \mathrm{ns}\end{array}$ & $\begin{array}{c}2.751 \\
(0.074) \mathrm{ns}\end{array}$ & $\begin{array}{c}1.008 \\
(0.373) \mathrm{ns}\end{array}$ & $\begin{array}{c}2.714 \\
(0.076) \mathrm{ns}\end{array}$ \\
\hline $\mathrm{B} \times \mathrm{H}$ & $\begin{array}{c}\mathrm{F} \\
\text { (P-value) }\end{array}$ & $\begin{array}{r}20.783 \\
(0)^{* *}\end{array}$ & $\begin{array}{r}71.395 \\
(0)^{* *}\end{array}$ & $\begin{array}{c}1.435 \\
(0.248) \mathrm{ns}\end{array}$ & $\begin{array}{c}3.263 \\
(0.047)^{*}\end{array}$ & $\begin{array}{c}0.272 \\
(0.763) \mathrm{ns}\end{array}$ & $\begin{array}{c}1.518 \\
(0.229)\end{array}$ \\
\hline $\mathrm{MMA} \times \mathrm{H}$ & $\begin{array}{c}\mathrm{F} \\
\text { (P-value) }\end{array}$ & $\begin{array}{c}6.454 \\
(0.014)^{*}\end{array}$ & $\begin{array}{r}68.171 \\
(0)^{* *}\end{array}$ & $\begin{array}{c}0.261 \\
(0.612) \mathrm{ns}\end{array}$ & $\begin{array}{r}176.963 \\
(0)^{* *}\end{array}$ & $\begin{array}{r}17.806 \\
(0)^{* *}\end{array}$ & $\begin{array}{c}0.622 \\
(0.434) n s\end{array}$ \\
\hline $\mathrm{B} \times \mathrm{MMA} \times \mathrm{H}$ & $\begin{array}{c}\mathrm{F} \\
\text { (P-value) }\end{array}$ & $\begin{array}{c}3.568 \\
(0.036)^{*}\end{array}$ & $\begin{array}{r}140.401 \\
(0)^{* *}\end{array}$ & $\begin{array}{c}0.546 \\
(0.583) \mathrm{ns}\end{array}$ & $\begin{array}{c}3.361 \\
(0.043)^{*}\end{array}$ & $\begin{array}{c}0.025 \\
(0.975) \mathrm{ns}\end{array}$ & $\begin{array}{c}0.527 \\
(0.594) \mathrm{ns}\end{array}$ \\
\hline
\end{tabular}

Notes: $\mathrm{B}$, MMA and $\mathrm{H}$ indicated boron preservatives, methyl methacrylate, and heat treatments.

* significant effect $(\mathrm{P}<0.05)$; ** very significant effect $(\mathrm{P}<0.01) ; n s$, not significant effect. 
heat treatment at $180{ }^{\circ} \mathrm{C}$. This result was in accordance with Kartal et al. (2007) that water absorption of heatmodified wood decreases with increasing temperature and heating time. Li et al. (2011) also reported that wood moisture content reduced by high temperature heating.

The lowest water absorption in this research was achieved by MMA impregnation with heating at $90{ }^{\circ} \mathrm{C}$. This corresponds to Hadi et al. (2013) that MMA treatment could reduce wood moisture content because of the formation of hydrophobic material in wood. A very low water absorption of red jabon wood was also achieved by boric acid and MMA impregnation followed by heating at $90{ }^{\circ} \mathrm{C}$.

\subsection{Dimensional stability}

Dimensional stability was an important property of wood influenced by environmental conditions, especially temperature and humidity. Wood dimensional stability was evaluated based on anti-swelling efficiency $(A S E)$. Fig. 3 showed that heat treated red jabon wood had positive $A S E$ value, meaning its dimensional stability increased. In general, heating at $180{ }^{\circ} \mathrm{C}$ resulted higher $A S E$ value of the wood than heating at $90{ }^{\circ} \mathrm{C}$. This was consistent with Bekhta and Niemz (2003) that heated wood was more stable with increasing temperature and heating time. Kocaefe et al. (2008) also reported that heat treatment at $130{ }^{\circ} \mathrm{C}$ could modify the hydrophilic polymer of the wood that became more hydrophobic and improved wood dimensional stability.

$A S E$ of red jabon wood increased after MMA impregnation, which might be caused by water inhibition by MMA polymer in wood. As Koubaa et al. (2012) reported that MMA impregnation filled voids in wood structures of fast-growing poplar clones. This was in accordance with Ding et al. (2011) that MMA impregnation could increase the density and dimensional stability of wood.

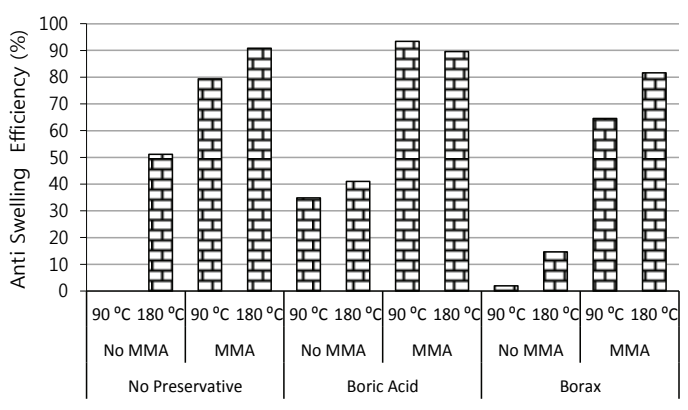

Fig. 3. Anti-swelling efficiency of modified red jabon wood with impregnation and heating.

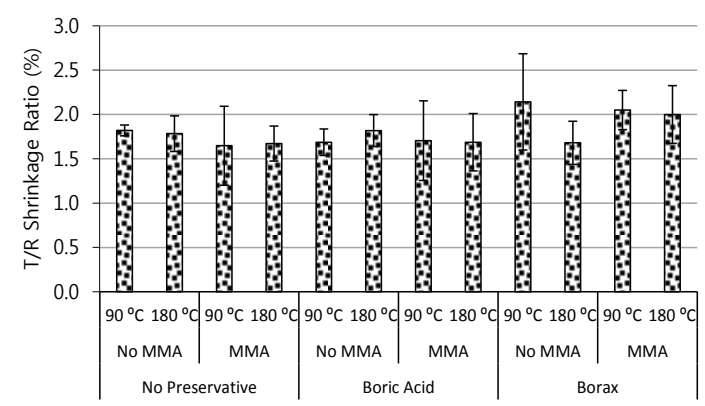

Fig. 4. Tangential-radial shrinkage ratio of modified red jabon wood with impregnation and heating.

Boron impregnation affected the tangential-radial shrinkage ratio ( $T / R$ ratio) of red jabon wood. The $T / R$ ratio of wood impregnated with boric acid was lower than the wood impregnated with borax (Fig. 4). This meant that boric acid impregnation resulted better dimensional stability of wood than borax impregnation. $T / R$ ratio closing to 1 showed better dimensional stability of wood, while Bowyer et al. (2007) stated that $T / R$ ratio exceeding 2 indicated worse wood dimensional stability. MMA impregnation resulted in a lower $T / R$ ratio compared to untreated red jabon wood. According to Hadi et al. (2013) MMA treatment had a bulking effect in wood shrinkage. In this research, the bulking effect showed to be a slight more in tangential direction than in radial direction of red jabon wood. 
Dimensional Stability, Color Change, and Durability of Boron-MMA

Treated Red Jabon (Antochephalus macrophyllus) Wood

\subsection{Wood color}

Impregnation and heat treatment changed the color of red jabon wood. The color change mainly occurred after MMA treatment, while boric acid and borax preservatives did not cause color change significantly. Different heating temperatures also affected the color of wood (Fig. 5). This supported Hill (2007) that the color change of wood was affected by the temperature and time of heating. Heat treatment at $180{ }^{\circ} \mathrm{C}$ decreased brightness value $\left(L^{*}\right)$ of red jabon wood, mainly those previously impregnated with MMA (Fig. 6). The reddish value $\left(a^{*}\right)$ of modified red jabon wood was relatively unchanged, except a slight decrease of $a^{*}$ after impregnation of borax and heating $90{ }^{\circ} \mathrm{C}$. The yellowish value $\left(b^{*}\right)$ was not clearly affected by boron preservation. The $b^{*}$ value of MMA impregnated red jabon wood increased by heating at $90{ }^{\circ} \mathrm{C}$, but decreased by heating at $180{ }^{\circ} \mathrm{C}$.

The color change value $\left(\Delta E^{*}\right)$ of red jabon wood occurred significantly after MMA impregnation, especially those heated at temperatures of $180{ }^{\circ} \mathrm{C}$ (Fig. 7). Preservation with boric acid and borax caused only a

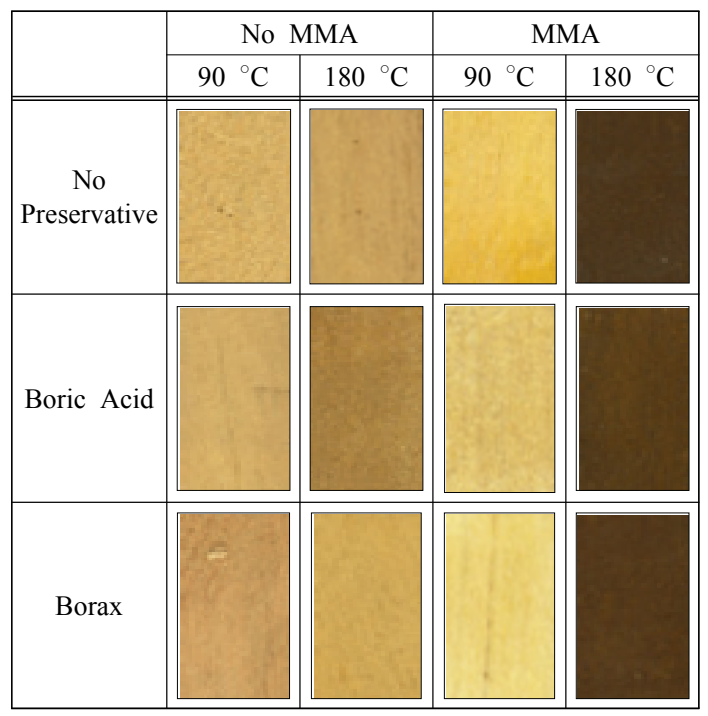

Fig. 5. The color of modified red jabon woods.

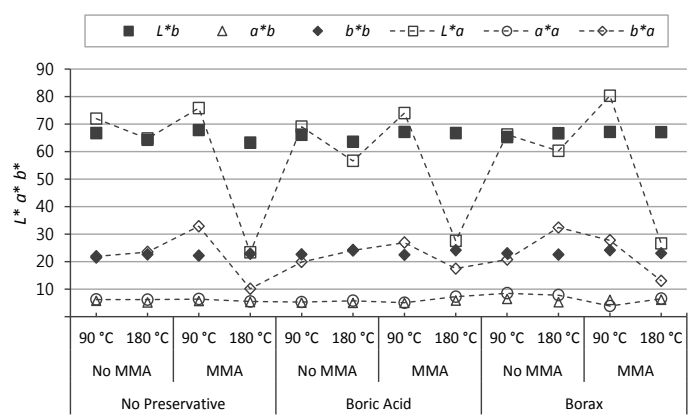

Fig. 6. The $L^{*}, a^{*}, b^{*}$ values of modified red jabon wood with impregnation and heating. $L^{*}, a_{b}^{*}, b^{*}$ : before impregnation and heating; $L^{*}{ }_{a}, a^{*}{ }_{a}, b^{*}{ }_{a}$ : after impregnation and heating.

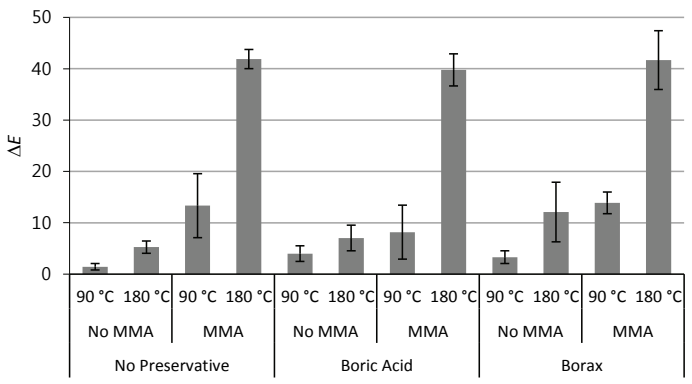

Fig. 7. Color change $(\Delta E)$ of modified red jabon wood with impregnation and heating.

slight increase in the $\Delta E^{*}$ value of red jabon wood, while heating at $180{ }^{\circ} \mathrm{C}$ on borax treated wood resulted in higher $\Delta E^{*}$ value than that on boric acid treated wood.

Color changes in wood due to heating could be related to the change or movement of extractives (Mohareb et al., 2010), polysaccharides change (Sahin and Korkut, 2016, Gaff et al., 2019, Cahyono et al., 2020), or related to the formation of carbonyl groups from the oxidation of hydroxyl group in the phenolic components or the formation of quinoid structures from adjacent hydroxyl groups (Wei et al., 2017).

\subsection{The resistance to decay fungi}

This research showed that boron preservative, MMA and heat treatment generally increased the resistance 


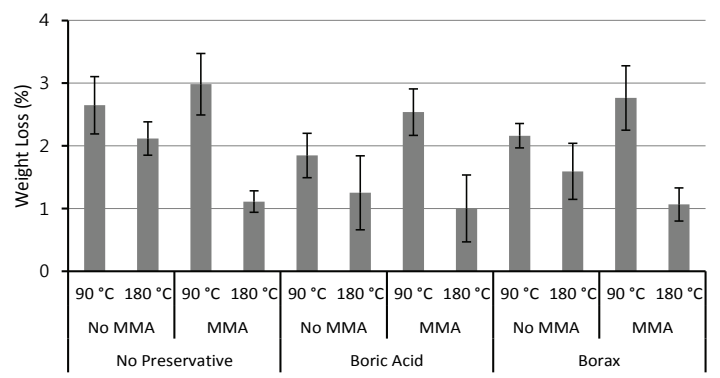

Fig. 8. Weight loss of modified red jabon wood in laboratory decay test.

of red jabon wood from decay fungi as indicated by a decrease in weight loss of the wood (Fig. 8). The analysis of variance and Duncan test at $95 \%$ confidence interval showed that weight loss of boron (boric acid and borax) impregnated woods were significantly lower than the control. A similar result was showed by Kartal et al. (2004) that boron treated wood was more resistant to brown-rot fungus Fomitopsis palustris and white-rot fungus Trametes versicolor. Moreover, this research showed that boric acid impregnation resulted more resistant wood against white-rot fungi, Schizophylum commune than that of borax impregnation treatment. In addition, heating at $180{ }^{\circ} \mathrm{C}$ improved the resistance to fungi as indicated by a lower weight loss than that of heating at $90{ }^{\circ} \mathrm{C}$. MMA impregnation followed by heating at $180{ }^{\circ} \mathrm{C}$ improved the resistance to fungi significantly, while those heated at $90{ }^{\circ} \mathrm{C}$ were not significantly different from the control. The lowest weight loss value occurred in red jabon wood that was impregnated with boric acid and MMA followed by heating at $180{ }^{\circ} \mathrm{C}$.

\subsection{Decay field test}

Ground contact durability test of wood was evaluated based on its weight loss. According to Priadi (2011) termites and decay fungi were the main wood-degrading organisms that attack wood in ground contact.

This research revealed that boron impregnation,

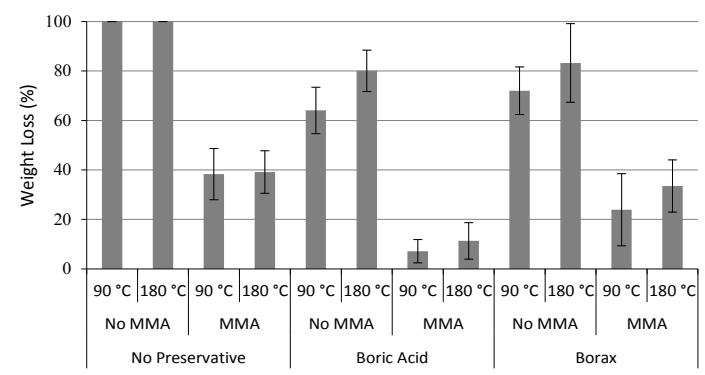

Fig. 9. Weight loss of modified red jabon wood in field decay test.

MMA impregnation or heat treatment improved wood durability that indicated by lower values of weight loss than that of the untreated wood (Fig. 9). The analysis of variance and Duncan test at $95 \%$ confidence interval also proved that the weight loss of impregnated red jabon wood with boric acid or borax was significantly lower than the control sample. In addition, MMA impregnated wood also has a prominent smaller weight loss than the wood without MMA impregnation. According to Kartal et al. (2004), MMA could maintain the presence of boron compounds in wood from leaching and become more resistant to the termites of Coptotermes formosanus Shiraki. Besides, according to Hadi et al. (2015), MMA treatment improved the resistance of jabon wood against Coptotermes curvignathus subterranean termites. MMA is not toxic to termites but can inhibit termite attacks on wood.

\section{CONCLUSION}

Boron impregnation, MMA impregnation as well as heat treatment resulted in dimensional stability and durability improvement of red jabon wood. MMA treatment with heating at $90{ }^{\circ} \mathrm{C}$ reduced water absorption and leaching of boron preservative from red jabon wood. Impregnation of boric acid and MMA with a heating temperature of $180{ }^{\circ} \mathrm{C}$ increased the dimensional stability of the wood with an $A S E$ value of $81.71 \%$. The hygroscopicity of wood also decreased, which was in- 
Dimensional Stability, Color Change, and Durability of Boron-MMA

Treated Red Jabon (Antochephalus macrophyllus) Wood

dicated by water absorption reduction to $43.86 \%$. This treatment also increased the resistance of red jabon wood against decay fungi and subterranean termites.

\section{REFERENCES}

ASTM 2006. Standard Test Method of Evaluating Wood Preservatives by Field Test with Stakes (ASTM D 1758-06). American Society for Testing and Materials (ASTM) International, ASTM International, West Conshohocken, Pennsylvania. Aydemir, D., Gunduz, G., Altuntas, E., Ertas, M., Sahin, H.T., Alma, M.H. 2011. Investigating changes in the chemical constituents and dimensional stability of heat-treated hornbeam and uludag fir wood. BioResources 6(2): 1308-1321.

Bekhta, P., Niemz, P. 2003. Effect of high temperature on the change in color, dimensional stability and mechanical properties of spruce wood. Holzforschung 57(5): 539-546.

Bowyer, J.L., Shmulsky, R., Haygreen, J.G. 2007. Forest products and wood science: an introduction. Wiley-Blackwell Publishing, Ames. Iowa(US).

BSN 2014. Standar Nasional Indonesia (SNI) (Indonesian National Standard) 7207-2014. Testing for Wood Resistance to Destructive Organisms. BSN (Badan Standarisasi Nasional) (National Standardization Agency of Indonesia).

Cahyono, T.D., Darmawan, W., Iswanto, A.H., Priadi, T. 2020. Flexural Properties of Heat-Treatment Samama (Anthocephalus macrophyllus) wood Impregnated by Boron, Methyl Methacrylate. Journal of the Korean Wood Science and Technology 48(1): 76-85.

Cahyono, T.D., Darmawan, W., Yanti, H., Iswanto, A.H. 2020. Changes in chemical components with NIR spectroscopy and durability of samama wood treated with boron, methyl methacrylate and heat treatment. IOP Conference Series: Earth and
Environmental Science 454: 012094.

Cahyono, T.D., Ohorella, S., Febrianto, F. 2012. Beberapa Sifat Kimia dan Keawetan Alami Kayu Samama (Antocephallus Macrophyllus) terhadap rayap tanah. Ilmu dan Teknologi Kayu Tropis 10(2): 168-178.

Cahyono, T.D., Wahyudi, I., Priadi, T., Febrianto, F., Bahtiar, E.T., Novriyanti, E. 2016. Analysis on Wood Quality, Geometry Factor, and Their Effects on Lathe Check of Samama (Anthocephalus macrophyllus) Veneer. Journal of the Korean Wood Science and Technology 44(2): 828-841.

Cahyono, T.D., Wahyudi, I., Priadi, T., Febrianto, F., Darmawan, W., Bahtiar, E.T., Ohorella, S., Novriyanti, E. 2015. The quality of 8 and 10 years old samama wood (Anthocephalus macrophyllus). Journal of the Indian Academy of Wood Science 12(1): 22-28.

Chang, Y.-S., Han, Y., Eom, C.-D., Jeon, S., Yeo, H. 2019. Hygroscopic Property of Heat Treated Yellow Poplar (Liriodendron tulipifera) Wood. Journal of the Korean Wood Science and Technology 47(6): 761-769.

Christie, R.M. 2014. Colour chemistry. Royal Society of Chemistry, Cambridge(UK).

Coto, Z., Wahyudi, I., Hadiyanne, A. 2015. Improving Wood Quality Through Phisical Properties Enhancement for Fast-Growing and Small-Diameter Timber. IPB Press, Bogor(ID).

Cui, W., Kamdem, D.P., Rypstra, T. 2007. Diffuse reflectance infrared Fourier transform spectroscopy (DRIFT) and color changes of artificial weathered wood. Wood and Fiber Science 36(3): 291-301.

Ding, W.-D., Koubaa, A., Chaala, A. 2011. Dimensional stability of methyl methacrylate hardened hybrid poplar wood. BioResources 7(1): 0504-0520.

Dormer, W., Gomes, R., Meek, M.E. 1998. Methyl methacrylate. World Health Organization, Geneva.

Gaff, M., Babiak, M., Kačík, F., Sandberg, D., Turčani, 
M., Hanzlík, P., Vondrová, V. 2019. Plasticity properties of thermally modified timber in bendingThe effect of chemical changes during modification of European oak and Norway spruce. Composites Part B: Engineering 165: 613-625.

Hadi, Y., Rahayu, I., Dami, S. 2015. Termite resistance of jabon wood impregnated with methyl methacrylate. Journal of Tropical Forest Science 27(1): 25-29.

Hadi, Y., Rahayu, I., Danu, S. 2013. Physical and mechanical properties of methyl methacrylate impregnated jabon wood. Journal of the Indian Academy of Wood Science 10(2): 77-80.

Hadi, Y.S., Massijaya, M.Y., Zaini, L.H., Abdillah, I.B., Arsyad, W.O.M. 2018. Resistance of Methyl Methacrylate-Impregnated Wood to Subterranean Termite Attack. Journal of the Korean Wood Science and Technology 46(6): 748-755.

Halawane, J.E. 2015. Prospek pengembangan jabon merah, Anthocephalus macrophyllus (roxb.) havil: solusi kebutuhan kayu masa depan. Balai Penelitian Kehutanan Manado, Badan Penelitian Pengembangan dan Inovasi.

Hidayat, W., Qi, Y., Jang, J.H., Park, B.H., Banuwa, I., Febrianto, F., Kim, N.H. 2017. Color change and consumer preferences towards color of heat-treated Korean white pine and royal paulownia woods. Journal of the Korean Wood Science and Technology 45(2): 213-222.

Hill, C.A. 2007. Wood modification: chemical, thermal and other processes. John Wiley \& Sons, West Sussex, England.

Jebrane, M., Heinmaa, I. 2016. Covalent fixation of boron in wood through transesterification with vinyl ester of carboxyphenylboronic acid. Holzforschung 70(6): 577-583.

Kartal, S., Yoshimura, T., Imamura, Y. 2004. Decay and termite resistance of boron-treated and chemically modified wood by in situ co-polymerization of allyl glycidyl ether (AGE) with methyl methacrylate (MMA). International biodeterioration \& biodegradation 53(2): 111-117.

Kartal, S.N., Hwang, W.-J., Imamura, Y. 2007. Water absorption of boron-treated and heat-modified wood. Journal of Wood Science 53(5): 454-457.

Kartal, S.N., Terzi, E., Yoshimura, T. 2019. Performance of fluoride and boron compounds against drywood and subterranean termites and decay and mold fungi. Journal of Forestry Research.

Kim, Y.K., Kwon, G.J., Kim, A.R., Lee, H.S., Purusatama, B., Lee, S.H., Kang, C.W., Kim, N.H. 2018. Effects of Heat Treatment on the Characteristics of Royal Paulownia (Paulownia tomentosa (Thunb.) Steud.) Wood Grown in Korea. Journal of the Korean Wood Science and Technology 46(5): 511-526.

Kocaefe, D., Shi, J.L., Yang, D.-Q., Bouazara, M. 2008. Mechanical properties, dimensional stability, and mold resistance of heat-treated jack pine and aspen. Forest Products Journal 58(6): 88-93.

Koubaa, A., Ding, W.D., Chaala, A., Bouafif, H. 2012. Surface properties of methyl methacrylate hardened hybrid poplar wood. Journal of Applied Polymer Science 123(3): 1428-1436.

Lee, J.M., Lee, W.H. 2018. Dimensional Stabilization through Heat Treatment of Thermally Compressed Wood of Korean Pine. Journal of the Korean Wood Science and Technology 46(5): 471-485.

Lempang, M. 2014. Sifat dasar dan potensi kegunaan kayu jabon merah. Jurnal Penelitian Kehutanan Wallacea 3(2): 163-175.

Lesar, B., Kralj, P., Humar, M. 2009. Montan wax improves performance of boron-based wood preservatives. International Biodeterioration \& Biodegradation 63(3): 306-310.

Li, X.J., Cai, Z.Y., Mou, Q.Y., Wu, Y.Q., Liu, Y. 2011. Effects of Heat Treatment on some Physical Properties of Douglas Fir (Pseudotsuga Menziesii) 
Dimensional Stability, Color Change, and Durability of Boron-MMA

Treated Red Jabon (Antochephalus macrophyllus) Wood

Wood. Advanced Materials Research 197-198: 90-95.

Mohareb, A., Sirmah, P., Desharnais, L., Dumarçay, S., Pétrissans, M., Gérardin, P. 2010. Effect of extractives on conferred and natural durability of Cupressus lusitanica heartwood. Annals of forest science 67(5): 504-504.

Muberra, G. 2016. Effects Of Boron Compound on Characteristics of Poly (Methyl Methacrylate) and Its Nanocomposites. Thesis, Middle East Technical University, Ankara, Turkey.

Park, Y., Han, Y., Park, J.-H., Chung, H., Kim, H., Yang, S.-Y., Chang, Y.-S., Yeo, H. 2018. Evaluation of Deterioration of Larix kaempferi Wood Heattreated by Superheated Steam through Field Decay Test for 12 Months. Journal of the Korean Wood Science and Technology 46(5): 497-510.

Priadi, T. 2011. Wood decay hazard analyses of residential buildings in Java Island. Dissertation, Bogor Agricultural University, Bogor(ID).

Priadi, T., Sholihah, M., Karlinasari, L. 2019. Water Absorption and Dimensional Stability of Heattreated Fast-growing Hardwoods. Journal of the Korean Wood Science and Technology 47(5): 567-578.

Priadi, T., Suharjo, A.A.C., karlinasari, L. 2019. Dimensional stability and colour change of heat-treated young teak wood. International Wood Products Journal 10(3): 119-125.

Romagnoli, M., Cavalli, D., Pernarella, R., Zanuttini, R., Togni, M. 2015. Physical and mechanical characteristics of poor-quality wood after heat treatment. IForest 8(6): 884-891.

Sahin, H. T., Korkut, S. 2016. Surface colour changes of turkish hazelnut wood caused by heat treatment. Journal of Advances in Biology \& Biotechnology 6(1): 1-7.

Salman, S., Pétrissans, A., Thévenon, M. F., Dumarçay, S., Perrin, D., Pollier, B., Gérardin, P. 2014. Development of new wood treatments combining boron impregnation and thermo modification: effect of additives on boron leachability. European Journal of Wood and Wood Products 72(3): 355-365.

Sandberg, D., Kutnar, A., Mantanis, G. 2017. Wood modification technologies-a review. iForestBiogeosciences and Forestry 10(6): 895-908.

Tomak, E.D., Viitanen, H., Yildiz, U.C., Hughes, M. 2011. The combined effects of boron and oil heat treatment on the properties of beech and Scots pine wood. Part 2: Water absorption, compression strength, color changes, and decay resistance. Journal of Materials Science 46(3): 608-615.

Wei, Y., Wang, M., Zhang, P., Chen, Y., Gao, J., Fan, Y. 2017. The role of phenolic extractives in color changes of locust wood (Robinia pseudoacacia) during heat treatment. BioResources 12(4): 70417055 .

Williams, L.H., Amburgey, T.L. 1987. Integrated protection against lyctid beetle infestations. IV. Resistance of boron-treated wood (Virola spp.) to insect and fungal attack. Forest products journal 2(37): 10-17.

Yalinkilic, M.K., Tsunoda, K., Takahashi, M., Gezer, E.D., Dwianto, W., Nemoto, H. 1998. Enhancement of biological and physical properties of wood by boric acid-vinyl monomer combination treatment. Holzforschung 52(6): 667-672. 